\title{
FACTORS AFFECTING POUCH MILK PURCHASE IN KATHMANDU
}

\author{
Sajeeb Kumar Shrestha* \\ *Associate Professor, Shanker Dev Campus, Kathmandu, Faculty of Management, TU
}

\begin{abstract}
This research attempts to measure factors affecting pouch milk purchase in Nepalese context. Positivist approach was used and descriptive and causal study was designed. Questionnaire survey was done and structured questionnaires were designed to collect data. Subjects of the study were respondents who purchase pouch milk regularly for household consumption. 200 samples were taken based on convenience sampling method. Data were analyzed thoroughly by reliability analysis, descriptive statistics, correlation analysis and regression analysis. The research confirmed quality and brand name had influence on pouch milk purchase decision. No support was found for price, availability and promotion in pouch milk purchase context.
\end{abstract}

Keywords: pouch milk - consumer purchase intention - quality and brand name.

\section{INTRODUCTION}

Consumer buying behaviour relates to how a consumer buys, uses and disposes a product to satisfy his needs (Kotler \& Keller 2011). Consumer may be individuals, groups and an organization. Consumer is king and queen in marketing so consumer behavior has profound effect on marketing. Consumer purchase is shaped by internal and external factors (Kotler \& Keller 2011). For low involvement product, consumer does not need to spend much time to purchase the product. For high involvement, consumer much time to evaluate, select and purchase the products. Consumer also needs after sales service.

Milk is said to be nutrient food and easily available as fluid or pouch in the rural and urban areas of Nepal. DDC sells average of 75,000 liters of standard milk daily (DDC Hikes Milk Prices 2017). There are about 500,000 households engaged in the dairy market as producers and sellers of milk. Milk production on $2017 / 18$ for first eight month was 19,50,602 
Metric Tonne. (Ministry of Finance, 2017/18). Milk production was noted as 1,724,000 Metric Tonne (Ministry of Finance, 2015). Contribution of cow milk was estimated to 557,000 MT (32 percent) while the buffalo milk at 1,167,000 MT (68 percent) (Ministry of Finance 2015). Pouch or packet branded milk is sold in Nepalese urban or rural markets. Various brands of pouch milks are available in Nepalese markets. There is also common market of selling fluid milk where farmers visit customers home to home and sell in desired quantity.

Price is what a consumer paid for what he gets (Kotler 2008). Consumer estimates a price range ranges about the product and accept the product within his price ranges (Raju 1977). Some consumer is very price sensitive that he switches to another cheaper brand. Man is an economic person; so he evaluates the price of every product he purchases. Brand is a customer's commitment to purchase a preferred product frequently (Oliver 1997). Brand does communicate "Buy me" as an alternative of saying "This is what I am" (Koirala 2015). It is the mental picture of brand identity (Koirala 2015). Brand represents the present and future identity of the organization (Emami \& Dimov 2017, Emami \& Talebi 2011). Customer acceptance of the brand means brands are sustained in the market (Kotler 2001).

Quality means a customer's perception about the superiority of the product than other products (Aaker 1991). Brand knowledge helps customer to determine the quality of desired product. Quality provides a cue to purchase the product. Quality motivates customer to become loyalty and makes company's marketing programs sound. Koirala (2015) argue that availability enhances the products to be bought and used. When the product is available the market, there is chance that it will fulfill the need of the customer. There is chance that it can be sold.

Purchase intention means consumer has favorable attitude toward product and shows interests to purchase the product (Kim \& Ko 2012). Evaluation of purchase intention helps marketers to estimate future sales of the company (Kim \& Ko 2012). Purchase intention support and moves the customers towards purchase process. Consumer purchase intention is important for consumer to behave (Day 1969). Real purchase is possible when purchase intention is initiated (Fishbein \& Ajzen 1975, Oliver \& Bearden 1985).

Anojan and Subaskaran (2015) found price, brand names, availability, promotion has impact on consumer buying decisions. Lal, Yambrach and McProud (2015) confirmed price and product quality influence consumer behavior. When consumer purchases pouch milk, 
consumer considers all the aspect like price, brand name, quality, availability and promotion independently. There is lack of research in consumer purchase on pouch milk in Kathmandu especially. So, the aim of the research is to examine factors affecting pouch milk purchase in Kathmandu.

The following research questions were highlighted for this research:

- What are the factors affecting pouch milk purchase in Kathmandu?

- What is the relation between milk purchase variables?

- Which factor influence most on pouch milk purchase in Kathmandu? Objectives of the study were set in the following.

- To analyze the factors affecting pouch milk purchase in Kathmandu.

- To measure the relation between milk purchase variables.

- To examine which factor influence most on pouch milk purchase in Kathmandu?

\section{Independent Variable}

Dependent Variable

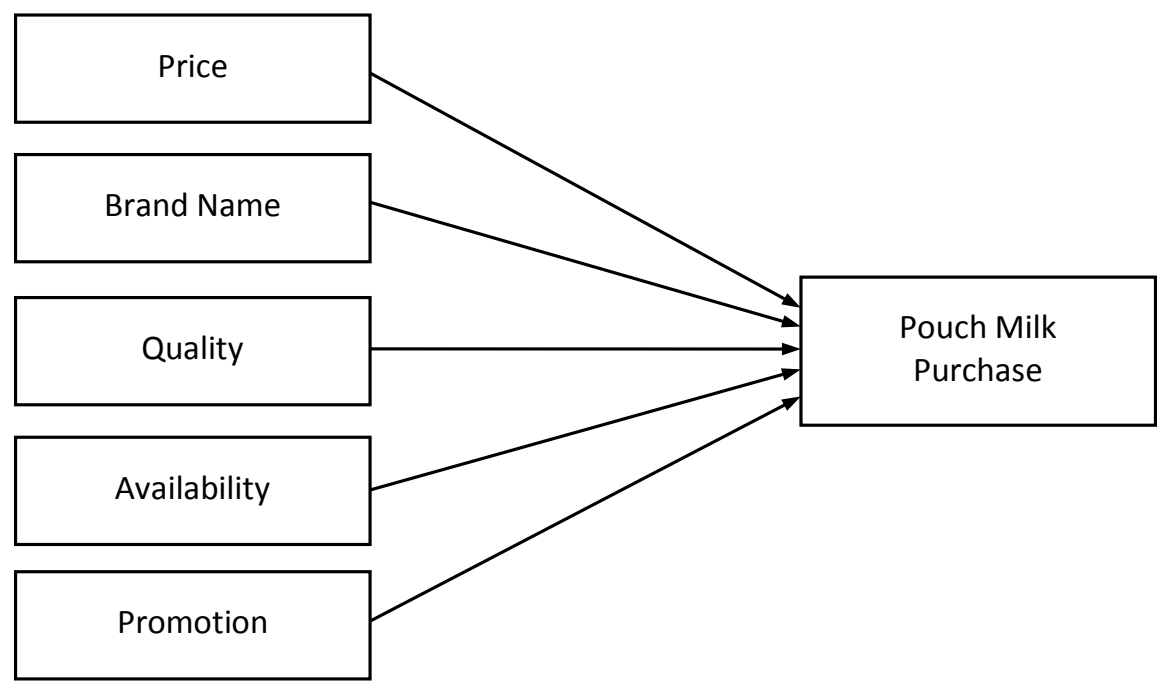

Figure 1: Conceptual frame

Source: Anojan \& Subaskaran, 2015; Lal et al., 2015)

Price, brand name, quality, availability and promotion has relation with consumer behavior (Anojan \& Subaskaran 2015, Lal et al. 2015). So, this research assumed as Price influence pouch milk purchase (H1). Brand influence pouch milk purchase (H2). Quality influence pouch milk purchase (H3). Availability influence pouch milk purchase (H4). Promotion influence pouch milk purchase (H5). 


\section{METHODOLOGY}

The purpose of the study was to analyze the factor affecting pouch milk purchase in Kathmandu. Descriptive and explanatory research design was used to fulfill the research objective. Research constructs were drawn from thoroughly reviewing the extant literature. Positivist approach was used for this research. So, the research is said to be quantitative research. There are three reasons for using quantitative research. First, research hypotheses should be clearly designed (Creswell 2009). This research had clearly shown hypotheses (H1-H5). Second, Sample of the study should be representative. Third, quantitative data were collected, analyzed and tested. Questionnaires survey was done to collect quantitative data.

Population of this study was the respondents reside in the Kathmandu City who was regularly purchasing pouch milk in the near local shop. Sample of the research was 200 samples in Kathmandu City. The sample size for this study is large enough for analysis purpose (Kline 2011). Kline depicts less than 100 samples are considered as small samples, between 100 to 200 samples are said 'medium samples' and over 200 samples are considered to be large enough. Also Eldred (1987) suggest that for most types of marketing research, samples of 100 to 200 respondents are enough to obtain meaningful results. Convenience samples were taken for data collection.

Research instrument is a structured questionnaire anchoring five point Likert Scales denoting "1 - Strongly Disagree" to "5 - Strongly Disagree". Constructs included in the research instruments were price, brand name, quality, availability, and promotion as independent variables and pouch milk purchase as dependent variables. Demographic variables were gender, age, income, and other related variables were frequency of milk purchase, daily consumption of milk, and monthly expenses on pouch milk purchase.

Data were collected from respondent approaching them in Kathmandu City and requested them to fill the questionnaires. Respondents were selected as they were regularly purchasing pouch milk.

Frequency analysis was done to show the basic demographic information plus other pouch milk purchase related information. Reliability analysis was done to check the internal consistency of the questionnaires used in the research. Descriptive statistics was used to highlight and summarize the constructs. Correlation analysis was done to check relationship between dependent variable with independent variables. Multiple regression analysis was run to highlight the impact of cause variables on result variables as well 
as test the hypotheses assumed. For data analysis and testing of hypotheses, SPSS 25 software was used.

The study expressed that that 59 percent of the respondents were male and 51 percent of the respondents were female. Majority of the respondents were higher secondary having 36 percent and bachelor graduates having 26 percent. Thirty-nine percent of the respondents were businessmen while 25 percent were student and 18 percent respondents were housewife. Large number of respondents was representing 45 percent on 25 to 35 year age category, followed by 19 percent in 25 to and 45 years and again 19 percent 45 and above age category.

\section{RESULTS AND DISCUSSION}

Majority of the respondents accounted of 45 percent preferred DDC milk. Rests are preferred Sitaram and Today pouch milk. 80 percent of the respondents purchase pouch milk daily. Milk becomes their regular purchase items. 40 percent of the respondents purchased milk in 1-2 liter quantity daily. 35 percent of the respondents purchased below 1 liter daily. 38 percent of the respondents spent Rs. 3,000- Rs. 4,000 in purchasing pouch milk. 45 percent of the respondents spent Rs. 1,000- Rs. 2, 000 in purchasing pouch milk.

Reliability analysis was used to check the internal consistency of the questionnaires. Cronbach's Alpha Value was and indicator for reliability of the scale items used in the questionnaire (George \& Mallery 2009).

Table 1: Reliability analysis

\begin{tabular}{ccc}
\hline Code & Constructs & Cronbach's Alpha \\
\hline PR & Price & 0.63 \\
BN & Brand Name & 0.65 \\
QL & Quality & 0.66 \\
AV & Availability & 0.62 \\
PR & Promotion & 0.77 \\
PI & Pouch Milk Purchase & 0.81 \\
\hline
\end{tabular}

Source: Survey, 2019

Table 1 reported the Cronbach's Alpha Coefficient value of price, quality, availability, promotion and pouch milk purchase was greater than 0.2 to 0.81 which is satisfactory for further analysis purpose (George \& Mallery 2009).

Descriptive statistics summarized the data in compact nature. Mean and Standard deviation were used to explain the data (Allen \& Seaman 2007, Thompson 2009). When the data reported mean value greater than 3 
it was viewed as respondents gave positive response to Likert statements. Descriptive statistics is shown in Table 2.

Table 2: Descriptive statistics

\begin{tabular}{ccc}
\hline Constructs & Mean & Standard deviation \\
\hline Price & 3.56 & 0.74 \\
Brand Name & 4.12 & 0.80 \\
Quality & 4.13 & 0.59 \\
Availability & 3.77 & 0.68 \\
Promotion & 3.82 & 0.77 \\
Pouch Milk Purchase & 3.66 & 0.75 \\
\hline
\end{tabular}

Source: Survey, 2019

Table 2 expressed quality and brand name is considered more by respondents having mean value of 4.13 and 4.12 respectively with standard deviation of 0.59 and 0.80 . Mean must be greater than three and standard deviation must be less than one. In Table 2 , all the mean value of the constructs was greater than 3 with standard deviation is less than one (Thompson 2009). So, the analysis can be generalized.

Correlation analysis is run to test whether there exists relation between two constructs. It shows the relative change in one variable to another variable. Correlation shows the degree and direction of relation. The relation may be weak, moderate and strong with positive or negative direction. Correlation analysis is done in Table 3 . The value of correlation coefficient (r) lies between '-1' to '+1'. Levin and Fox (2006) reports when value of ' $r$ ' lies below 0.3 , it is said weak correlation. When the value of ' $r$ ' lies between $0.30-0.60$, it is called moderate correlation (Levin \& Fox 2006). When value of ' $r$ ' is greater than 0.6 , it is called strong correlation (Levin \& Fox 2006). Correlation analysis was done in Table 3.

Table 3: Correlation matrix

\begin{tabular}{ccc}
\hline Construct & Correlation & Pouch milk purchase \\
\hline Price & Correlation & 0.45 \\
& Sig. & 0.00 \\
Brand Name & Correlation & 0.16 \\
& Sig. & 0.00 \\
Quality & Correlation & 0.21 \\
& Sig. & 0.00 \\
Availability & Correlation & 0.42 \\
& Sig. & 0.00 \\
Promotion & Correlation & 0.49 \\
& Sig. & 0.00 \\
\hline
\end{tabular}

Source: Survey, 2019 
Table 3 highlighted the correlation between study constructs. Pouch milk purchase is moderately correlated with price $(\mathrm{r}=0.45)$, with availability $(\mathrm{r}=0.42)$ and with promotion $(\mathrm{r}=0.49)$ (Levin \& Fox 2006). It was found weak correlation between pouch milk purchase with brand name $(\mathrm{r}=0.16)$ and with quality $(\mathrm{r}=0.21)$ (Levin \& Fox 2006).

Regression assumptions were tested before running regression analysis. Normality, Linearity, Multicollinearity, and independence of error showed satisfactory results that regression assumptions were not violated (Cohen, Cohen, West \& Aiken 2003, Pedhazur 1997, Tabachnick \& Fidell 1996)

Regression analysis was done to check the impact of cause variable on result variable. It is also used to test the hypothesis. Regression analysis is shown in Table 4.

Table 4: Regression Analysis

\begin{tabular}{ccc}
\hline Cause variable & Coefficient value of $\boldsymbol{\beta}$ & Sig. \\
\hline Constant & 1.820 & 0.000 \\
Price & 0.066 & 0.406 \\
Brand Name & 0.101 & 0.045 \\
Quality & 0.142 & 0.034 \\
Availability & 0.050 & 0.281 \\
Promotion & 0.030 & 0.145 \\
\hline
\end{tabular}

Result variable: Pouch milk purchase

$\mathrm{R}=0.42 ; \mathrm{R}^{2}=0.34 ;$ Adj. $\mathrm{R} 2=0.32 ; \mathrm{S} . \mathrm{E} .=0.35 ; \mathrm{F}$-Value = 45.47;

$\mathrm{p}$-value of $\mathrm{F}$ test $=0.000$.

Sig. at $5 \%$ level

Source: Survey, 2019

Table 4 showed F-value and p-value of regression model was 45.47 and 0.000 accordingly that is significant at $5 \%$ level of significance. So, the model became linear. $\mathrm{R}$ square of this model was 0.34 or $34 \%$ that means the model is estimated $34 \%$ in pouch milk purchase by variation of price, brand name, quality, availability and promotion construct.

Form Table 4, p-value of brand name and quality is significant at $5 \%$ level of significance. So, $\mathrm{H} 2$ and $\mathrm{H} 3$ are accepted. Brand name and quality influence pouch milk purchase. P-value of price, availability and promotion is not significant at 5\% level of significance. So, H1, H4 and H5 are not accepted. Price, availability and promotion does not influence pouch milk purchase. 


\section{CONCLUSION}

This research is aimed to examine factors affecting pouch milk purchase in Kathmandu City. From literature price, brand name, quality, availability and promotion are the factors of pouch milk purchase in Kathmandu City. After testing hypothesis, brand name and quality factors are the most influencing factors for pouch milk purchase in Kathmandu. No support was found for price, availability and promotion factors. Customers are giving more emphasis on price and quality while buying pouch milk. Nepalese marketing are still on growing era, so brand name are least preferred by customers. Pouch milk is non durable convenient goods so it is available everywhere. Customers think not more about its availability for purchasing purpose. Promotion on pouch milk is rare. So, promotion is not an effective tool for selling pouch milk. This research is consistent with Anojan and Subaskaran (2015) and Lal et al. (2015) that quality and brand name influence pouch milk purchase. It is better to say marketers should also consider brand name and quality factors while making strategy for pouch milk.

\section{WORKS CITED}

Aaker, D. (1991). Managing brand equity, capitalizing on the value of a brand name. New York: Free Press.

Allen, E. \& Seaman, C.A. (2007). Likert scales and data analyses. Quality Progress, 5(40): 64-65.

Anojan, V. \& Subaskaran, T. (2015). Consumers preference and consumers buying behavior on soft drinks: A case study in Northern Province of Sri Lanka. Global Journal of Management and Business Research: E-Marketing, 15(2): 11-33. https://journalofbusiness. org/index.php/GJMBR/article/view/1687/1590

Chandra Lal, R., Yambrach, F. \& McProud, L. (2015). Consumer perceptions towards package designs: A cross cultural study. Journal of Applied Packaging Research, 7(2), 61-94. https://scholarworks.rit.edu/cgi/ viewcontent.cgi?article $=1026 \&$ context $=$ japr

Cohen, J., Cohen, P., West, S.G. \& Aiken, L.S. (2003). Applied multiple regression/correlation analysis for the behavioral sciences (3rd ed.). Mahwah, NJ: Lawrence Erlbaum Associates.

Cresswell, J. W. (2009). Mapping the field of mixed methods research. Journal of Mixed Methods Research, 3(2): 95-108. 
Day, G. S. (1969). A two-dimensional concept of brand loyalty. Journal of Advertising Research, 9(3): 29-35.

DDC. (2017, August 17). The Himalayan Times. https://thehimalayantimes. com/nepal/dairy-development-corporation-hikes-milk-prices/

Eldred, G. (1987). Real estate: Analysis and strategy. New York: Harper \& Row.

Emami, A. \& Dimov, D. (2017). Degree of innovation and the entrepreneurs' intention to create value: A comparative study of experienced and novice entrepreneurs. Eurasian Business Review, 7(2): 161-182.

Emami, A. \& Talebi, K. (2011). Decision framing and critical success factors of new product development. African Journal of Business Management, 5(15): 6233-6239.

Fishbein, M. \& Ajzen, I. (1975). Belief, attitude, intention, and behavior: An introduction to theory and research. Addison-Wesley Publishing Company. MA.

George, D. \& Mallery, P. (2009). SPSS for Windows, step by step (8th ed.). Delhi, Patparganj: Dorling Kindersley (India) Pvt. Ltd.

Kim, A.J. \& Ko, E. (2012). Do social media marketing activities enhance customer equity? An empirical study of luxury fashion brand. Journal of Business Research, 65(10): 1480-1486.

Kline, R. B. (1998). Principles and practice of structural equation modeling. New York: The Guilford Press.

Koirala, K. D. (2015). Brand management strategy. Kathmandu: M. K. Publishers \& Distributors.

Kotler, P. (2001). Marketing management (Millenium ed.). New Jersey: Pearson Custom Publishing.

Kotler, P. (2008). Marketing management (9th ed.). New Delhi: Prentice Hall.

Kotler, P. \& Keller, K.L. (2011). Marketing management (14th ed.). New Jersey, NJ: Prentice Hall.

Lal, R. C., Yambrach, F. \& McProud, L. (2015). Consumer perceptions towards package design: A cross cultural study. Journal of Applied Packaging Research, 7(2): 61-94.

Levin, J. \& Fox, J. A. (2006). Elementary statistics in social research (1st impression). Delhi, Patparganj: Dorling Kindersley (India) Pvt. Ltd., licensees of Pearson Education in South Asia. 
MoF. (2017). Economic survey 2017/18. Ministry of Finance, Government of Nepal, Kathmandu. https://mof.gov.np/uploads/document/ file/for\%20web_Economic\%20Survey\%202075\%20Full\%20 Final\%20for\%20WEB\%20_20180914091500.pdf

Oliver, R. L. (1997). A behavioral perspective on the consumer. New York, NY: McGraw-Hill.

Oliver, R. L. \& Bearden, W.O. (1985). Crossover effects in the theory of reasoned action: a moderating influence attempt. Journal of Consumer Research, 12(3): 324-340.

Pedhazur, E. J. (1997). Multiple Regression in behavioral research (3rd ed.). Orlando, FL: Harcourt Brace.

Raju, P. S. (1977). Product familiarity, brand name, and price influences on product evaluation. Advances in Consumer Research, 4(1): 64-71.

Tabachnick, B. G. \& Fidell, L.S. (1996). Using multivariate statistics (3rd ed.). New York: Harper Collins College Publishers.

Thompson, C. B. (2009). Descriptive data analysis. Air Medical Journal, 28(2): 56-59. 